This is a pre-publication version of: Margulis, Matias E. Forthcoming. 'Negotiating from the margins: How the UN shapes the rules of the WTO.' Review of International Political Economy.

\title{
Negotiating from the margins: How the UN shapes the rules of the WTO
}

\author{
Matias E. Margulis \\ Division of History and Politics, University of Stirling \\ Stirling FK9 4LA United Kingdom \\ +44(0) 1786467585 \\ m.e.margulis@stir.ac.uk
}

\begin{abstract}
:
World Trade Organization (WTO) rules on agriculture are among the most contentious issues in the international political economy due to agriculture's importance in the production of tradable commodities as well as economic development and food security in developing countries. In this article, I analyse a surprising and unexpected actor playing an important role in shaping WTO rules on agriculture - the United Nations (UN). While UN actors do not have a seat at the bargaining table, I argue that they invoke their delegated and moral authority and initiate actions to shape global trade rule-making. I demonstrate that UN actors have influenced the discourse, agenda and outcomes of trade negotiations by analysing three cases: 1) the Food and Agriculture Organization (FAO) orchestrating a Uruguay Round agreement in favour of food insecure developing countries; 2) the World Food Programme's (WFP) blocking of trade rules on international food aid during the Doha Round negotiations; and 3) a proposal by the UN Special Rapporteur on the right to food for a legal waiver to protect public food stockholding that was taken up by WTO member states in 2013.
\end{abstract}

\section{Key words:}

World Trade Organization (WTO); United Nations (UN); agriculture; food security; trade negotiations; international law; right to food; international organizations (IOs); non-state actors; authority. 


\section{Introduction}

Agriculture is among the most contentious issues in world trade politics - so contentious, in fact, that it was excluded from the international trade regime for nearly 50 years. Agriculture was finally brought under the trade regime in the General Agreement on Tariffs and Trade (GATT) Uruguay Round negotiations, however this almost did not come to pass due to repeated breakdown in the negotiations over the scale and pace of liberalization. Agriculture continues to remain a divisive policy issue for states - the World Trade Organization (WTO) Doha Development Round collapsed largely due to North-South disagreement on agricultural reform. One of the reasons agriculture is so highly contentious is its importance beyond the production of tradable commodities to the wider role it plays in economic development and food security, especially in the developing world. The United Nations (UN) reports that 2.5 billion people - a third of the world's population - depend directly on agriculture for their livelihoods. More than 800 million people are undernourished globally, despite the Millennium Development Goal target to reduce the number of hungry people worldwide to 485 million by 2015. Achieving food security remains a pressing global challenge, and the issue has gained increasing prominence and became a major source of political contestation in multilateral trade negotiations on agriculture. An important question is thus: Who makes the rules of global trade in agriculture?

Understanding how global trade rules are made and by whom has been a major preoccupation of International Political Economy scholarship (Chorev and Babb 2009; Deardorff 2004; Quark 2013). Traditionally, the trade literature has focused primarily on the competing preferences of, and asymmetric power relations among, states to explain the results of trade negotiations (Davis 2003; Hopewell 2016; Narlikar 2003; Wolfe 1998). Yet more recent research has shown that states are not the sole actors seeking to influence trade negotiations with transnational corporations (Hopewell 2013; Sell 2009), experts (Mably 
2009; Scott 2015) and global civil society (Eagleton-Pierce 2012; Hopewell 2015) revealed to be actors influencing the trade agenda. Although trade scholarship has increasingly opened the black box of multilateral trade negotiations to account for the role of non-state actors, the literature has largely overlooked the impact of UN institutions on global trade rule-making. In this article, I argue that actions initiated by UN institutions have had major impacts on WTO rule-making on agriculture. The agentic role of UN institutions in shaping trade rules is a phenomenon that has been rarely identified nor systematically analysed in the existing trade literature.

In the analysis that follows I show that UN institutions have acted as agents of change that instigate purposeful action and have successfully influenced the discourse, agenda and outcomes of multilateral trade negotiations. The claim that UN institutions have had significant impacts on WTO rule-making is surprising and runs counter to expectations in the literature. Whereas trade scholarship acknowledges that international organizations (IOs) such as the UN play important supporting roles at the WTO, such as sharing expertise and information, providing assistance to developing countries and facilitating the implementation of agreements (Hannah, Ryan and Scott 2017; Prowse 2002; VanGrasstek 2013), they are not generally regarded as influential actors in their own right but rather as servants of states and lacking the capacity to act on their own volition (see Barnett and Finnemore 2004; Chorev 2012). I suggest a different conceptualization of IOs in the trade regime as instigators of targeted interventions to alter the course of multilateral trade negotiations. I demonstrate the plausibility of this claim with an analysis of three case studies showing that the UN Food and Agriculture Organization (FAO), UN World Food Programme (WFP), and UN Special Rapporteur on the right to food all influenced the rules of the WTO by intervening in multilateral trade negotiations on agriculture. 
The article contributes to the literature on global trade politics by unearthing the previously unrecognized role of the FAO, WFP and Special Rapporteur on the right to food in GATT/WTO negotiations and their impacts on rule-making. In contrast to the prevailing view that IOs are peripheral players in multilateral trade negotiations, this study shows that UN actors can wield significant influence over the course and outcome of negotiations. This article also challenges the assumption that IOs only act when prompted to by states: the case studies demonstrate that UN agencies were self-directed actors and instigators of targeted interventions in trade negotiations in order to achieve their goals and preferred outcomes. The article establishes that UN institutions are engaged in more impactful and complex roles in the trade regime than previously thought. This study thus enhances our knowledge of who shapes the rules of the WTO and advances efforts to build a multi-actor approach to explaining trade politics in which IOs are key agents.

The article is organized as follows. The first section identifies how the literature has analysed IOs in global trade politics and introduces the conception of IOs as agents of change. The second section sets out the research design, case selection criteria and methodology used to undertake the research. The third section provides evidence to support the claim that UN institutions initiate actions and successfully exert influence in trade negotiations by demonstrating: (1) the role of the FAO in orchestrating an agreement in favour of developing countries during the GATT Uruguay Round; (2) the role of the WFP in blocking WTO rules on international food aid at the 2005 Hong Kong Ministerial; and (3) the role of the UN Special Rapporteur on the right to food in shaping agreement at the WTO on a legal waiver for public food stockholding. 


\section{The role of IOs in the multilateral trade system}

I draw on and apply insights from the literature on IOs as actors (Barnett and Finnemore 2004; Biermann and Siebenhüner 2009; Broome, Homolar and Kranke forthcoming; Chorev 2012; Hawkins et al. 2006; Oestreich 2012) to show that existing conceptions of the role of IOs at the WTO are too limited. To date, trade scholarship has conceived the role of IOs in trade negotiations in three principal ways: as providers of demand-driven assistance, producers of technical trade knowledge, and observers participating through official channels.

First, trade scholarship has emphasized the role of IOs in providing demand-driven assistance to states (Prowse 2002; Shaffer 2005; Smeets 2013). Commonly referred to as 'trade-related capacity building', such assistance involves the training of GATT/WTO member state officials in technical trade matters, assisting developing country delegations to prepare their negotiating proposals, and providing technical policy and legal advice on trade proposals (Deere 2005). Developing countries are the main recipients of such assistance because they often lack adequate representation in Geneva and the human and financial resources to adequately prepare for and fully participate in negotiations (Prowse 2002; Wilkinson 2014). Such assistance is considered demand-driven (Hannah 2014) because it is provided by IOs at the request of states. IOs such as the World Bank, United Nations Conference on Trade and Development (UNCTAD) and United Nations Development Programme (UNDP) are all engaged in providing demand-driven assistance to states at the WTO. ${ }^{1}$ Indeed, UNCTAD, the one UN institution with a trade mandate, has the provision of demand-driven assistance to developing countries in the WTO negotiations written into its core functions (Hannah, Ryan and Scott 2017; Taylor 2003; UNCTAD 2004: 44-51). In contrast, however, the cases of the FAO, WFP and Special Rapporteur on the right to food illustrate that IOs' engagement in trade negotiations can be precipitated without requests by states for assistance; instead, these UN actors were the instigators of purposeful actions 
intended to influence the course of trade negotiations. We know from the literature on IOs that they are agents with their own interests and goals (Barnett and Finnemore 2004; Hawkins et al. 2006: 24-25). The fact that IOs are actors in their own right and capable of initiating independent action has been firmly established (Chwieroth 2009; Oestreich 2012; Reinalda and Verbeek 1998). Applying these insights to the context of the WTO, I make the case that other IOs can undertake self-directed actions to shape multilateral trade negotiations.

Second, existing trade scholarship suggests that IOs feed ideas into the negotiations because they can claim technical trade expertise. IOs such as the World Bank, International Monetary Fund (IMF), UNCTAD and the Organization for Economic Cooperation and Development (OECD) employ dozens of trade experts that are highly active and influential within the epistemic communities and transnational networks involved in producing and disseminating knowledge about how trade works (Babb and Chorev 2016; Hannah, Scott and Trommer 2015). Such technical trade knowledge is frequently used by states to inform their bargaining positions (Hannah, Ryan and Scott 2017; Mably 2009; Shaffer 2005). The case studies presented here, however, illustrate that producing technical trade knowledge is not the sole way UN actors try to influence trade negotiations. The WFP, which specializes in the delivery of emergency food assistance, has no claim to trade expertise. Instead, the WFP, for instance, invoked its unique role in feeding the world's most vulnerable people to challenge rule-making at the WTO. Similarly, the Special Rapporteur on the right to food, whose specialized knowledge is of international human rights law and not technical trade matters, intervened in the negotiations by claiming to be protecting universal human rights. The fact that IOs draw on a mix of diverse sources of authority is a key insight from the literature on IO as actors in world politics (Barnett and Finnemore 2004: 27; Bauer and Ege 2017; Broome and Seabrooke 2015; Johnson 2013). Barnett and Finnemore (2004: 20-26, 30-34) identify four types of authority that enable IOs to shape the world: rational-legal authority, which is 
based on the perception that an organization embodies impartial rules and neutrality; delegated authority to perform specialized functions and tasks; expert authority in the form of trusted knowledge; and, moral authority claims to defend the interests and values of the international community. IOs are more able to exert influence when they are recognised as the leading authority in a policy field (Chwieroth 2009) or when they claim to be upholding universal values (Barnett and Finnemore 2004: 23). Drawing on these insights, I argue that IOs are not solely reliant on technical trade knowledge but can draw on other forms of authority, such as delegated and moral authority, to influence the course and outcomes of WTO trade negotiations. This points to a wider scope of IO engagement with the trade regime that is not limited to technical trade matters but includes more political forms of advocacy.

Lastly, trade scholarship points to the importance of official cooperation of IOs with the WTO. Other IOs are involved in ensuring policy coordination and legal consistency with the WTO and managing areas of shared competence (Babb and Chorev 2016; Gehring and Faude 2014). Existing scholarship has focused on IOs' interaction with the WTO through formal, official channels, including the 'policy coherence' mandate governing coordination between the WTO, World Bank and IMF (Grabel 2007) and IOs with observer status to the WTO that support the work of its committees and decision-making bodies (Lang and Scott 2009; VanGrasstek 2013). In contrast to the expectation in the literature that IOs' engagement with the WTO takes place primarily through official channels, the cases presented here indicate that UN actors also undertake actions outside of the formal boundaries of cooperation with the WTO. The WFP and Special Rapporteur relied on the media and the court of global public opinion to contest trade rules, whereas the FAO worked behind the scenes to mobilize a coalition of states. Not only can IOs engage in the trade negotiations 
outside formal channels but it is, I argue, often through unofficial channels that they are most effective in shaping WTO rules.

Thus, in contrast to the existing trade literature that perceives IOs' role in trade negotiations as limited to demand-driven assistance, reliant on technical trade knowledge and operating through official channels, I call for a more expansive view of IOs as agents that may initiate their own interventions, which may be not just technical but also political, draw on multiple, diverse forms of authority beyond technical expertise, and operate outside of formal channels at the WTO. Building on the arguments outlined above, I now introduce a different conceptualization of IOs' role in the trade regime - as agents of change that undertake self-initiated actions to influence the discourse, agenda and outcomes of multilateral trade negotiations. What makes this conceptualization of IOs in trade politics distinct from the existing trade literature is that it takes as its starting point a recognition of IOs' agency in seeking to influence the course of trade negotiations.

Why do IOs seek to influence multilateral trade negotiations? I argue that IOs are driven to intervene, including behaving in ways counter to the preferences of powerful states, when they perceive trade negotiations to have consequences for achieving their own social purpose. Every IO has a distinct social purpose, most simply understood as their goals for shaping the world, which is determined by an organization's mandate, history and the normative orientation of their staff (Barnett and Finnemore 2004; Chwieroth 2009; Nielson and Tierney 2003; Oestreich 2012). There has been a significant expansion in the scope and authority of WTO rules beyond traditional trade issues, such as tariffs, to encompass a wide range of other issues with implications for a growing number of policy fields - including the environment, intellectual property rights, and public health, among others (Barton et al. 2010; Muzaka 2011). The result is that developments in multilateral trade negotiations carry widereaching consequences for the goals of other IOs. I argue that IOs decide to intervene in trade 
negotiations when they believe that proposed trade rules will have harmful consequences for their core areas of responsibility and efforts to realize their goals. This motive behind IOs' efforts to shape WTO rules suggests that their actions are not limited to improving the bargaining capacity of developing countries or ensuring these countries benefit from trade, which, by comparison, is the primary goal of demand-driven assistance activities (Deere 2005; Hannah, Ryan and Scott 2017). The fact that IOs may intervene in GATT/WTO negotiations in an effort to further their social purpose is illustrated in the three case studies that follow: as I will show, the FAO, WFP and Special Rapporteur sought to influence the negotiations because these actors anticipated that trade rules would worsen global food insecurity, an outcome they perceived to run counter to their mandates and goals to create a world free from hunger.

Given that IOs lack a seat at the bargaining table, how do we know if their actions impact the negotiations in a meaningful way? For the purposes of this article, meaningful impacts in the context of multilateral trade negotiations are defined as an IO actor's influence on the discourse, agenda or outcomes. Influencing discourse refers here to the ability to introduce new, or alter existing, framings and understandings of trade issues that shape how states act in negotiations (see Wilkinson 2009). To change discourse, IOs must persuade states to perceive a trade issue (and its consequences) differently than they would have otherwise. Agenda-setting refers to the process of delimiting the range of issues under consideration in the negotiation (Murphy 2010). Agenda-setting matters at the WTO because it defines the stakes at play in the negotiations and directly shapes the range of possible outcomes (Albin and Young 2012; Steinberg 2002: 354-356). Here, influencing the agenda is defined as the ability of an IO actor to successfully insert, block or remove issues on the bargaining table. Lastly, IO actors can be said to influence the negotiation outcomes if their self-initiated action shapes an official decision taken by the WTO membership and/or 
translates into the substantive content of a trade agreement or practices of the trade regime. A couple of caveats must be introduced before proceeding. First, this is not to suggest that IO actors automatically or always intervene in trade negotiations. Such interventions are costly in terms of time and human and financial resources, and also carry reputational and political risks (such as if an IO's effort fails or it incurs the wrath of powerful states for being perceived to be undermining their interests). As a result, decisions by IOs to intervene are not likely to be taken lightly. Second, IOs do not operate in a vacuum. In addition to states, many non-state actors orbit multilateral trade negotiations - such as transnational corporations, think tanks and global civil society - and are involved in efforts to shape trade rules. The analysis presented here therefore seeks to discern the impact of specific IOs within a complex, multi-actor setting.

\section{Research design and methods}

The central purpose of this article is to draw attention to an important but previously unknown phenomenon in global trade rule-making: other IOs have acted as agents of change that influence the course and outcomes of trade negotiations at the GATT/WTO. ${ }^{2}$ The study is thus best described as a plausibility probe (Eckstein 2009; Levy 2008), in which illustrative cases are presented to provide evidence of a previously unknown relationship. By establishing the existence of a phenomenon, a plausibility probe can serve as the basis for future hypothesis construction and theory development (Eckstein 2009). Consistent with the objective of a plausibility probe, in this study, I am intentionally selecting on the dependent variable - meaning selecting cases where other IOs have successfully influenced GATT/WTO negotiations - in order to demonstrate the existence of this previously unknown relationship between other IOs and the GATT/WTO. 
Here, I focus on illustrative cases from multilateral trade negotiations on agriculture, because it is one of the most high-profile and contentious issues in the trade regime and has been the subject of extensive scholarship. Remarkably, despite the fact that agriculture is one of the most studied areas of WTO negotiations, existing scholarship has failed to sufficiently acknowledge the significant role of UN actors. ${ }^{3}$ Analysing three distinct cases of UN actors intervening to influence WTO negotiations provides a higher threshold of evidence than a single-case research design (George and Bennett 2005) and confirms that this phenomenon is not an isolated incident but a repeated occurrence. The cases analysed represent a diverse range of institutions with different mandates and resources (see Table 1) - from the FAO with its thousands of staff and multi-billion dollar budget to the Special Rapporteur on the right to food whose team consists of just a handful of individuals and operating on a shoestring budget. The cases also encompass IOs with and without official observer status at the WTO (see Hannah, Ryan and Scott 2017). The interventions analysed here occurred over a range of different time periods - from the GATT Uruguay Round (1986-1994) to the WTO Doha Round (2001-2011) to the post-Doha period ${ }^{4}$ - and on a range of different issues including balance of payments problems, international food aid, and public food stockholding. The illustrative cases demonstrate that intervention by UN institutions in multilateral trade negotiations is not a one-off, isolated event but part of a larger phenomenon, occurring across different periods of time, on multiple issues, and by multiple institutions - all of which suggests that this is an important phenomenon worthy of greater attention by trade scholars. 
Table 1. Diversity of IO actors intervening in global trade-rule making

\begin{tabular}{|l|l|l|l|l|l|l|}
\hline Actor & $\begin{array}{l}\text { Year } \\
\text { created }\end{array}$ & $\begin{array}{l}\text { Organizational } \\
\text { Type }\end{array}$ & Mandate & $\begin{array}{l}\text { Issue area of } \\
\text { authority }\end{array}$ & $\begin{array}{l}\text { Observer } \\
\text { status to the } \\
\text { GATT/WTO }\end{array}$ & $\begin{array}{l}\text { Number of staff } \\
\text { and annual } \\
\text { budget }\end{array}$ \\
\hline FAO & 1945 & $\begin{array}{l}\text { Specialized } \\
\text { agency }\end{array}$ & $\begin{array}{l}\text { End hunger and } \\
\text { improve } \\
\text { developing } \\
\text { country } \\
\text { agriculture }\end{array}$ & $\begin{array}{l}\text { Agricultural and } \\
\text { food security } \\
\text { policy }\end{array}$ & Yes & 4000 staff \\
\hline WFP & 1961 & Programme & $\begin{array}{l}\text { Provides food } \\
\text { assistance in } \\
\text { emergencies and } \\
\text { improve } \\
\text { nutrition }\end{array}$ & $\begin{array}{l}\text { Humanitarian } \\
\text { relief }\end{array}$ & Yes & billion \\
\hline $\begin{array}{l}\text { Special } \\
\text { Rapporteur } \\
\text { on the } \\
\text { right to } \\
\text { food }\end{array}$ & 2000 & $\begin{array}{l}\text { Independent } \\
\text { expert appointed } \\
\text { by the Human } \\
\text { Rights Council }\end{array}$ & $\begin{array}{l}\text { Promotion of } \\
\text { the human right } \\
\text { to food }\end{array}$ & $\begin{array}{l}\text { International } \\
\text { human rights }\end{array}$ & No & \$6 billion \\
\hline
\end{tabular}

I used process-tracing (George and Bennett 2005; Levy 2008), as this technique is particularly well-suited to explaining the dynamics of an outcome in a particular case. This method enabled me to carefully reconstruct events in GATT/WTO negotiations and identify when actions undertaken by UN actors had an impact on the discourse, agenda or outcomes of the negotiations. Multiple sources of qualitative data were collected and analysed from desk- and field-based research undertaken at the WTO and UN Human Rights Council in Geneva and the FAO and WFP in Rome between 2009 and 2015. Document analysis of over 300 texts covering the Uruguay and Doha rounds - including official summaries of negotiating sessions, bargaining proposals and statements by states, documents issued by the FAO, WFP and Special Rapporteur on the right to food, and international press coverage was used to construct a detailed chronology of the agricultural negotiations and identify interventions by IO actors. I also draw on 81 elite interviews with current and former officials from the FAO and WFP, and the Special Rapporteur on the right to food, all of which were involved in the specific events analysed, as well as with GATT/WTO secretariat officials, current and former trade negotiators, and NGOs and think tanks. In addition, I incorporate 
data from direct observation of several public and closed meetings at the WTO, FAO, UN Human Rights Council and other relevant events, such as workshops organized by NGOs and think tanks on the agricultural negotiations. Representative quotations drawn from the interview data are presented in the analysis to provide evidence of and context to interventions by UN actors.

\section{How the UN shapes the rules of the WTO}

A major catalyst for the FAO, WFP and Special Rapporteur on the right to food's efforts to influence trade negotiations, I argue, has been the delegation of global rule-making authority over agriculture to the GATT/WTO (See Coleman, Grant and Josling 2004; Margulis 2013). For most of the GATT's history, agriculture was effectively excluded from the trade regime due to resistance by the United States (US) and European Union (EU) to reduce farm protection. The situation changed with the launch of the GATT Uruguay Round of multilateral trade negotiations in 1986 after the US and EU decided to end their decades-long 'farm war' of competitive subsidization and establish a more liberal agricultural trade regime (Wolfe 1998). A key reason for this shift in position was that the farm war had become fiscally unsustainable - US spending on farm support had increased five-fold to $\$ 26$ billion in the 1980s (Paarlberg 1997: 419) - and difficult to defend politically as farm programs became framed as exemplars of government waste. The conclusion of the Uruguay Round in 1994 resulted in the establishment of the WTO and the Agreement on Agriculture under which developed and developing countries reduced and capped tariffs and agricultural subsidy spending levels. The agreement also moved to harmonize internal food and agricultural policies that acted as barriers to trade. The commitments undertaken by states on agriculture under WTO rules are 'hard' ones - they are binding under international law, monitored by a surveillance mechanism and enforced by a dispute settlement system. The 
impacts of the agricultural negotiations remain contested. Many believe, for example, that developing countries' weaker bargaining position resulted in an unbalanced agreement skewed against their interests (Bukovansky 2010).

Agriculture and food security policy are deeply intertwined, especially in developing countries that have relatively high rates of hunger and malnutrition and where a significant part of the population depends on small-scale farming for economic survival. While the relationship between agricultural liberalization and food security has been long debated in the trade regime (Margulis 2017), the creation of the WTO was a transformative event that made trade rules consequential in a new way by defining the policy space available to states to pursue food security objectives (Clapp 2015; Daugbjerg, Farsund and Langhelle 2017). Agriculture has also been a major issue of disagreement between developed and developing countries in the Doha Round; disagreement over future agriculture trade rules was a key reason for the breakdown of the Doha negotiations (Hopewell 2016). I argue that the power of WTO rules, and potential impacts of trade negotiations for world food security, motivates the FAO, WFP and UN Special Rapporteur on the right to food to seek to influence the negotiations.

\section{The FAO in the Uruguay Round}

In the first case, I show that during the GATT Uruguay Round negotiations FAO officials were instrumental in mobilizing developing countries to put food security concerns on the negotiating agenda and were the architects of the 1994 WTO Decision on Measures Concerning the Possible Negative Effects of the Reform Programme on Least-Developed and Net Food-Importing Developing Countries - an agreement with the goal of safeguarding the food security of developing countries. Although strong proponents of agricultural liberalization (Farsund, Daugbjerg and Langhelle 2015), FAO officials were propelled to 
intervene in the negotiations because of their belief that liberalization would result in higher food prices for the poor. This case illustrates that FAO officials initiated efforts to shape the negotiations but largely operated behind the scenes by orchestrating a bargaining coalition of developing countries around the issue of higher future food prices; in doing so they reframed the issue of food security from a discourse centred on hunger to one centred on macroeconomic instability, and they wrote rules that are now part of WTO law.

The FAO, whose mission is to end hunger and improve agricultural production, was a longstanding advocate of agricultural liberalization and openly welcomed the Uruguay Round negotiations. Multiple FAO reports and studies argued that reducing Northern farm subsidies would both address market distortions and, more importantly, improve the trade and economic situation of developing countries. Grasping the round's potential to benefit developing countries, FAO Director-General Edouard Saouma was not content for the organization to be limited to providing information and technical assistance; he sought an active role for the FAO and made an extraordinary request by directly asking GATT members to grant his officials observer status in the agricultural negotiations (FAO 1986). Citing the FAO's unique expertise on food policy and agricultural commodities, Saouma wanted FAO officials to directly monitor the talks and be on site to proactively offer advice to trade negotiators. Developed countries resisted this request. They distrusted the highly activist Saouma (Shaw 2007: 235) and in trying to justify blocking his request argued that 'active involvement in these sensitive negotiations by any multilateral organization' was 'inappropriate' (FAO 1987a: 45). Despite their efforts to keep the FAO at bay, developed countries eventually relented after Saouma enrolled GATT developing country members to support his request for observer status; however, they agreed only on the condition that the World Bank and IMF, whom they hoped would serve as counterweights to the FAO, be granted equivalent status. 
The negotiations raised big questions about the expected winners and losers from agricultural liberalization. While developed countries, supported by a chorus of economists in academia and the international financial institutions, touted the net global welfare gains to be had from liberalization, developing countries voiced concerns that reform would have adverse effects on their food security. Over 50 GATT members were net food-importing developing countries (NFIDCs) that depended on cheap, subsidized Northern foodstuffs such as wheat flour, grains and vegetable oils to meet domestic food needs. Liberalization was intended to reduce US and EU government-held agricultural surpluses and thus lead to a contraction of world food supply and higher prices. World Bank and OECD studies at the time predicted liberalization would increase world prices by as much as $18 \%$ for wheat, $25 \%$ for corn and 21\% for rice (FAO 1987b: 21-23). Higher prices were a paramount concern for NFIDCs given that they faced difficulties purchasing adequate levels of foodstuffs due to declining terms of trade and high debt levels. NFIDCs feared they would be the main losers from agricultural liberalization and voiced demands that the 'interests of those who could be forced to pay more for their food and could least afford to do so' be at the forefront of the negotiations (GATT 1988a: 2). Yet the NFIDCs faced difficulty getting their concerns on the negotiating agenda, which had been designed to accommodate the diverging positions among the US, EU, Japan and the Cairns Group of agricultural exporting countries on farm subsidy reform and tariffs. ${ }^{5}$ Those states had the most bargaining power: they were the largest agricultural producers, markets and users of farm support and thus had the most 'skin in the game'. In contrast, NFIDCs held little leverage in the negotiations; they were not major users of farm subsidies (most could not afford them) and many had already undertaken unilateral tariff cuts (as part of structural adjustment programs), leaving them with very little to put on the table in exchange for concessions and thus in a weak bargaining position. 
NFIDCs' initial objective was to get the issue of higher food prices on the negotiating agenda. Lacking technical expertise, their initial bargaining approach in the round was one of resistance (Narlikar 2003: 150-151). They issued broad political declarations, such as that the agricultural negotiations would increase hunger or threaten domestic political stability in developing countries. Such declarations did not sway developed countries, which responded by demanding that NFIDCs bring concrete proposals to the bargaining table. FAO officials, who were sympathetic to the NFIDC's plight and saw higher future food prices as a serious risk to world food security, took the decision to work with NFIDCs and help them develop a concrete bargaining strategy on food security. ${ }^{6}$

FAO officials suggested to NFIDC trade negotiators that they adopt a different set of demands centred on requests for multilateral financial assistance to minimize anticipated balance of payments difficulties caused by future rising food import bills. NFIDCs trusted the advice of FAO officials because the organization was the authority on food policy and had backed developing countries' position against the Bretton Woods institutions by being a vocal critic of structural adjustment (Shaw 2007). NFIDC trade negotiators incorporated FAO officials' suggestions and these were initially brought forward in the agricultural negotiations by Jamaica in a 1988 bargaining proposal that called for compensatory measures and financial assistance for food imports. A joint proposal was subsequently tabled by Egypt, Jamaica, Mexico and Peru - all NFIDCs - with similar demands. These proposals demonstrate that FAO officials had persuaded NFIDCs to repackage their demands by framing the 'problem' as one of balance of payments rather than hunger. Moreover, the NFIDCs took up bargaining positions in their proposals that were tied to policy goals pursued by senior FAO staff at the time. This is most evident in NFIDCs' demand in the agricultural negotiations for additional balance of payments financing from the IMF: this idea can be traced back to FAO recommendations for a special cereal import facility during the 1974 
World Food Crisis. The FAO's recommendations were eventually implemented under the IMF’s Compensatory Financing Facility; however, by the mid-1980s FAO senior management were frustrated by the fund's conditionality requirements, which shut out countries with the greatest needs, but were unsuccessful in lobbying the IMF Executive Board for changes (Shaw 2007). The agricultural negotiations therefore provided FAO officials with an opportunity to reopen the international debate on the issue of multilateral financing for food imports at the GATT by persuading NFIDC negotiators to make requesting additional multilateral financial assistance a central bargaining demand in the agricultural negotiations.

The FAO-inspired bargaining demand by NFIDCs for balance of payments support proved to have greater traction in the negotiations than their earlier political declarations. In the context of the 1980s Third World debt crisis and global economic slowdown, a proposal to ensure that agricultural liberalization did not amplify macroeconomic instability resonated strongly with conventional economic thinking and the interests of the developed countries. It was also a credible negotiating demand given the balance of payments difficulties experienced by NFIDCs in the years prior to the launch of the round (see Table 2). Simply put, the FAO's framing of higher food prices as a balance of payments problem - which is determined by a country's trade balance - made the NFIDC's request for additional financing fit better with economistic ways of thinking at the GATT. NFIDCs' proposals, strengthened by wider support from developing countries, persuaded developed countries to add the issue to the negotiating agenda. The official change to the negotiation agenda took place at the 1988 Montreal Ministerial, where trade ministers achieved consensus that 'special attention should be given to the possible negative effects of short-term measures on net food-importing developing countries' and to prioritise work on the issue in the agricultural negotiations (GATT 1988b: 13). Getting their concerns on the agenda was a significant victory for the 
NFIDCs. It was also a significant success for FAO officials as it achieved their long-standing goal of reopening international debate on food-related balance of payment problems.

Table 2. Current Account Balance as Percentage of Gross Domestic Product (Balance of Payments, in US\$ 2017), average, selected countries and years

\begin{tabular}{|l|l|l|}
\hline Country & $\mathbf{1 9 8 0 - 1 9 8 5}$ & $\mathbf{1 9 8 6 - 1 9 9 0}$ \\
\hline Egypt & -5.136 & -0.968 \\
\hline Jamaica & -10.359 & -3.269 \\
\hline Morocco & -7.555 & -0.407 \\
\hline Mexico & -1.415 & -0.956 \\
\hline
\end{tabular}

Source: International Monetary Fund, Balance of Payments Statistics Yearbook and data files, and World Bank and OECD GDP estimates. Author calculations.

In the aftermath of the Montreal Ministerial, and in a bid to prioritize staff time and energy, FAO senior management took the independent decision to make supporting the NFIDCs in the agricultural negotiations a priority (FAO 1991a: 521-2). Although the GATT negotiations created many demands on the FAO's limited resources, FAO officials saw it as their responsibility to help fast-track the development of a collective NFIDC bargaining proposal, which despite two years of work had not yet materialized due to internal disagreements (Walch 2003). External events also played a key role in prompting FAO officials to devote greater energy to NFIDCs as poor harvests in Asia, Europe and North America led to record low levels of world grain stocks and a food price increase of nearly $20 \%$; this added $\$ 3$ billion to NFIDCs' food import bills, worsened macroeconomic conditions and led to reduced food consumption among the poor (FAO 1990; FAO 1991b). These events heightened FAO officials' concerns about the consequences of a GATT trade deal lacking adequate food security protection, driving new work to channel their expertise and resources to assist NFIDCs develop a bargaining strategy and coordinate their work to present a unified front in the negotiations. 
FAO officials' role behind the scenes in coordinating the work of the NFIDCs was crucial in producing their first collective bargaining proposal. In this proposal, NFIDCs stated that their main objective was to 'alleviate the burden of increased prices on the import bill and balance-of-payments situation of net food-importing developing countries' (GATT 1989: 1). The proposal had broader significance as it marked the arrival of the Net Importers Group - a new developing country bargaining coalition in the agriculture negotiations. The proposal signalled a more technical approach by NFIDCs to bargaining. The Group's proposal, for example, requested they be provided with offsetting measures such as government to government concessional (i.e., below market price) food sales and additional financial resources for NFIDCs as compensation for higher food prices. They also demanded developed countries create a multilateral fund to pay for the offsetting measures out of their 'savings' from future agricultural subsidy expenditures (GATT 1989: 4). The FAO's fingerprints are found all over the Net Importers Group proposal, ranging from its technical sophistication on multilateral financing to the statistical data prepared by the FAO secretariat. Once again, FAO officials saw the opportunity in the negotiations to advance long-standing food policy goals. The idea of a new multilateral fund was in fact a reworked FAO proposal from its 1979 Plan of Action on World Food Security, which had been an initiative championed by Saouma (Shaw 2017: xiii), to make new financial resources available to support agricultural development. Senior FAO staff had run into reservations from developed countries when it came to implementing the Plan in the early 1980s (Shaw 2007). The agricultural negotiations enabled FAO staff to try creating a new fund once again, however, this time as a tool to address food security problems anticipated from higher future food prices. The Net Importers Group proposal was as much the product of the FAO's labour as that of the NFIDC trade negotiators. Interviews with key informants confirmed the FAO's role in writing much of the Net Importers Group proposal, including advocating for the 
multilateral fund. ${ }^{7}$ FAO officials were deeply involved in informing both the content of the Net Importers Group's negotiation position and writing the bargaining text presented to other states at the negotiating table.

The FAO's most significant contribution occurred in the final stages of the Uruguay Round negotiations. A draft agricultural deal, known as the Framework Agreement on Agriculture Reform Programme, presented to ministers for decision at the 1990 Ministerial in Brussels was rejected by the Net Importers Group. The group had been incensed that the Framework made no mention of the offsetting measures or a multilateral fund, which NFIDCs had spent the previous 18 months negotiating. Jamaica, the group's de facto leader, announced that the Framework was not an adequate basis for addressing NFIDCs' concerns while Egypt accused developed countries of reneging on the 1988 Montreal Ministerial agreement to address food prices. FAO officials shared this view, fearing the food security situation of NFIDCs would deteriorate without adequate safeguards in future agricultural trade rules. Though the Net Importers Group threatened to walk out of the negotiations, the Brussels Ministerial broke down because the US and EU could not agree on a percentage cut to agricultural subsidies. With the Uruguay Round on the brink of collapse, the GATT Director-General, Arthur Dunkel, was tasked to broker a compromise solution. Dunkel adopted an exclusionary bargaining process that privileged small group negotiations among developed countries or bilaterally between the US and EU (Scott 2008: 88), however, he acknowledged NFIDCs' concerns were unresolved. In the weeks that followed, the Net Importers Group presented Dunkel with a new negotiating text outlining a compromise solution for addressing the issue of higher food prices. Much of this text had been written by FAO officials. Dunkel floated the text to developed countries in bilateral and plurilateral consultations $^{8}$ and eventually shepherded states towards a breakthrough agricultural deal in 1991. The deal included a Declaration on Measures Concerning the Possible Negative 
Effects of the Reform Programme on Net Food-Importing Developing Countries, which contained most of the elements promoted by senior FAO officials. The Declaration included a formal recognition by developed countries that agricultural liberalization could have 'negative effects' on world food supply and the ability of NFIDCs to secure 'adequate supplies of basic foodstuffs from external sources on reasonable terms and conditions, including short-term difficulties in financing normal levels of commercial imports' (GATT 1991: 213). It also committed developed countries to provide NFIDCs with additional international food aid, greater technical and financial assistance, and favourable access to agricultural export credits, and establish new funding facilities as required.

The 1991 Declaration thus signalled a major U-turn in the negotiations from one of negligible mention of NFIDCs' demands in the 1990 Framework to a full-fledged political commitment by developed countries to address the financing of food imports in the 1991 Declaration. NFIDCs were satisfied with the text of the Declaration, seeing it as a major negotiation victory given they held no bargaining power over the rich countries (Walch 2003). Meanwhile, the best endeavour nature of the Declaration made it agreeable to developed countries, which preferred a wait and see approach on what would happen to food prices in the future and to not commit themselves to providing financial aid up front. The Declaration thus resolved the negotiation impasse between NFIDCs and developed countries on agriculture. The Uruguay Round negotiation ended some months later when the US and EU reached consensus on the outstanding issues in agriculture at the Blair House meeting in 1992. Trade ministers met in Marrakesh in 1994 to sign the Final Act Embodying the Results of the Uruguay Round of Multilateral Trade Negotiations, which formally concluded the negotiations. The Final Act included the Declaration, which was retitled a 'Decision' (commonly referred to as the 'NFIDC Decision') and became one of the founding legal texts of the WTO. The food security safeguard for developing countries established in the NFIDC 
Decision, which had been heavily shaped by FAO officials and reflected their long-standing food policy goals, thus became part of global trade rules on agriculture.

The FAO's support to NFIDCs in the Uruguay Round agricultural negotiations was not demand-driven but initiated by senior FAO management because of concerns about world food security. NFIDCs did not formally request assistance from the FAO in the negotiations but deferred to its advice. Much of the FAO's involvement on food security in the negotiations took place outside of official channels; FAO officials operated behind the scenes in coordinating the work of the Net Importers Group and contributed to the substantive content of their negotiation proposals. The main negotiation successes of the Net Importers Group in the Uruguay Round agricultural negotiations - the recognition of balance of payments problem as a food security concern and agreement on the NFIDC Decision - was an outcome not likely to have been achieved without the targeted interventions by FAO officials. NFIDC trade negotiators lacked the research and bargaining capacity (Narlikar 2003; Walch 2003) to have come up with these ideas and proposals on their own. It was therefore not a coincidence that NFIDCs' bargaining strategy mirrored the food policy goals - goals which included expanding the provision of multilateral financing for commercial food imports and agricultural development - that FAO senior management had vigorously pursued in the years prior to the GATT Uruguay Round.

\section{The WFP in the Doha Round}

The WFP is the world's largest provider of emergency food aid and a key player in nutrition programming across the developing world. The WFP's decision to intervene in the WTO Doha Round negotiations is a particularly interesting case because its officials acted out of concerns that proposed trade rules to govern international food aid transactions would constrain the organization's ability to provide food assistance to vulnerable populations. WFP 
officials intervened in the negotiations to block new trade rules sought by WTO members. Unable to persuade trade negotiators to alter their bargaining positions spurred the WFP Executive Director to take unprecedented and drastic action by launching a media campaign that depicted trade negotiators as recklessly endangering the lives of hungry people. This highly public act generated international controversy yet ultimately proved successful as it stopped agreement on the WTO rules that WFP officials believed would have adverse consequences for world food security. The WFP's actions had a long-term effect on the dynamics of the agricultural negotiations with the 2015 WTO Ministerial Decision on Export Competition, in which states agreed to new trade rules addressing international food aid, incorporating key demands made by the WFP.

International food aid is a long-standing source of friction in trade politics. International food aid originated as a post-war policy in developed countries to dispose of surplus agricultural production. However, by the 1950s food aid was a major trade irritant and resulted in a series of deals negotiated at the GATT to prevent international food aid from undermining commercial food trade, including in the Uruguay Round Agreement on Agriculture (Clapp 2012).

Dissatisfied with the food aid disciplines in the Agreement, the Cairns Group of major agricultural exporters put international food aid on the agenda of the Doha Round agriculture negotiations. WTO members agreed to create new rules to restrict the use of surplus disposaldriven food aid and ban the practice of bulk food sales at below market prices - all food aid practices predominately used by the US. International food aid became further politicized in the Doha Round when the EU Trade Commissioner unilaterally offered to eliminate the EU's agricultural export subsidies in exchange for an equivalent concession from the US (Clapp 2012: 122-38). EU trade negotiators were under pressure to secure a major negotiating victory to placate Germany and France (whose trade ministers had called the EU's proposal 
on export subsidies a 'massive tactical mistake') and they targeted US food aid as the political scalp to be won. The US was reluctant to negotiate on food aid and told other delegations that their hands were tied due to political pressure from the powerful US food aid lobby, which had strong cross-party ties and for decades had blocked efforts to reform US international food aid programs. US trade negotiators claimed existing programs were legitimate, however their credibility was damaged in 2003 when it came to light that the US government had been shipping record-level quantities of skim milk powder as food aid to Asia through a subsidiary of Land O'Lakes, one of the US' largest commercial dairy producers. It was well-known at the time that the US was sitting on mounting dairy surpluses with no commercially viable export outlet. While the US claimed its skim milk powder food aid was to improve child nutrition, its actions ignited controversy as agricultural exporters accused it of flouting WTO rules (Bridges Weekly 2004). Adding fuel to the fire was a highly-publicized Oxfam report (Food Aid or Hidden Dumping?) that revealed US surplus disposal-driven food aid damaged the livelihoods of poor farmers abroad.

WFP officials, which had observer status, were passive actors in the early stages of the negotiations. They were reluctant to take sides in the negotiations, despite being the international authority for food aid, because of the political friction between the WFP's two principal donors - the US and EU. ${ }^{9}$ Instead, WFP officials focused on technical consultations and information-sharing in support of the negotiations. A key turning point in the negotiations for the WFP came in July 2004 when the chairperson of the negotiations presented a draft agricultural deal that proposed new rules to prevent the US from exporting surplus agricultural commodities as food aid and to provide the WTO authority to determine what constituted legitimate international food aid transactions. In exchange, the EU was expected to lock in a timeline to eliminate export subsidies. This issue linkage between food aid and export subsidies 'showed that food aid effectively became a bargaining chip among 
donor countries in the context of the broader agricultural trade negotiations' (Clapp 2012: 129).

With stalemate in agriculture holding up the rest of the Doha Round negotiations, there was intense pressure on WTO members to accept the agricultural deal with its new rules disciplining international food aid. As states moved into more intensive negotiations focused on finalizing the details on new food aid rules, WFP officials decided to change their approach away from one of passivity and began to press trade negotiators to reconsider the proposed rules. WFP officials were concerned by the politicization of food aid at the WTO given that real international food aid deliveries had fallen by almost $40 \%$ in the previous year, despite a growing number of humanitarian emergencies and increased global demand. In the context of declining resources and greater needs, the WFP representative to the negotiations told states that 'any [WTO] text dealing with food aid should at least reiterate the commitment by members to ensure the continuation and increase of levels of food aid' (Belgasmi 2006: 179). WFP officials held multiple informal meetings with EU and the Cairns Group negotiators in which they stressed that the proposed rules did not help to address real food security problems. ${ }^{10}$ In addition, WFP officials claimed that the rules would constrain the organization's operational flexibility to deliver food aid in emergencies if it was to be prevented from drawing on US agricultural surpluses, which remained an important resource at the time. WFP officials communicated to developed country negotiators of the need for assurances that any shortfall in food aid supply would be made up with additional resources to ensure world hunger did not worsen. ${ }^{11}$

With WTO members moving ever closer to agreement on the food aid rules, WFP officials stepped up their efforts by flying the WFP Executive Director to Geneva in the hope that trade negotiators might be brought around if the message came directly from the organization's top official. At a specially convened meeting with trade negotiators in spring 
2005, the WFP Executive Director, James T. Morris, stressed that he was 'absolutely opposed' to banning food aid sourced from surpluses (Williams 2005). In further discussions with WTO members, WFP officials expressed the organization's position on the agricultural negotiations as follows,

WFP feels that the most workable solution for WTO is not to focus on the source of food aid -- cash versus in-kind, surplus versus non-surplus -- but on its use. The question then is: Is this food aid donation being used to address bona fide emergencies or to assist vulnerable groups with clearly defined food security problems? Is food aid to a rural community where half the children are chronically malnourished and suffering from micronutrient deficiencies commercial displacement? Obviously not. These children and their families are not real participants in the commercial market. (Powell 2005: 6)

The crux of the WFP's message to negotiators was that trade politics were riding roughshod over food security goals. WFP officials also expressed their discomfort with any provision that would make the WTO the final arbiter of legitimate food aid, stressing that such a role was outside the competence of trade experts and should be left to humanitarian agencies (Margulis 2013). WFP officials sought to make clear how serious they were about their concerns and issued a warning to negotiators that WTO rules that resulted in further decreases in food aid 'would be both a moral and public relations disaster' (Powell 2005: 2). The WFP's warning was not well received by the EU and Cairns Group negotiators; they accused WFP officials of not being impartial and siding with the US. While it is well-known that the US wields significant influence at the WFP (it is the largest donor and appoints the Executive Director), there is no evidence that the US government requested the WFP to support its position in the negotiations. Suggesting the WFP was acting on behalf of the US in the negotiations obfuscates the fact that WFP officials had stated their support for many aspects of the proposed food aid rules advocated by the EU and Cairns Group, including a proposal to ban monetization - the practice of selling food aid for cash in recipient country markets - that the US fought hard to block. 
Tensions between the WFP and trade negotiators reached fever pitch at the December 2005 Hong Kong Ministerial. On the morning of the opening day of the ministerial, the WFP placed an advertisement in the Financial Times with the headline 'Don't Play with Our Food' and a photograph depicting emaciated African children with a caption asking, 'Will WTO's trade negotiators take food out of our mouths?'. The WFP also coordinated a joint press conference with the UN High Commissioner for Refugees (UNHCR) and Executive Director of the UN Children's Fund (UNICEF) where they stated that the proposed WTO rules threatened the food security of vulnerable groups (UN News Centre 2005). The Financial Times advert garnered significant global media attention; the story that the UN had said WTO negotiators were trying to starve hungry children dominated press coverage of the Ministerial. Prior to Hong Kong, food aid had been a relatively minor issue in the negotiations but it had unexpectedly turned into the one of the biggest public relations disasters for the WTO. Heri and Häberli (2011) argue that the WFP's advert was a total shock to trade negotiators; they had not foreseen such an intervention by the WFP, with several negotiators expressing the view that a UN agency should not have been so publicly and directly involved in lobbying on a sensitive WTO negotiating issue (Khor 2005). The advert drew a strong rebuke from the EU Trade Commissioner, Peter Mandelson, who stated 'I find it shocking that United Nations agencies should be financing an advertisement in the Financial Times that is designed to support the US' trade distorting policies on food aid' (EU 2005).

Debate over the proposed food aid rules and the WFP's intervention played out in the media. EU member governments responded in the Financial Times with a letter to the editor entitled 'UN Agencies' Advert is an Insult to all WTO Members', in which they accused the WFP of being part of a group of 'entrenched interests' who were not ready to reform food 
aid. While the EU sought to implicate the US behind the WFP's action, the US Trade Representative, Rob Portman, was adamant the WFP had acted alone,

First, the United States did not put in any ad or article in the Financial Times. That was the United Nations agencies that did it. It's a free world. If people want to put ads in the newspaper, they can do that. We didn't put any ads in anywhere (USTR 2005)

The WFP Executive Director also shot back, stating that the ad was not intended to bolster any particular state's position but that it had been a decision taken among senior UN officials to prevent the humanitarian needs of food insecure populations from being 'diminished in the quest for a trade agreement' (Morris 2005).

The WFP's public condemnation of the proposed WTO food aid rules carried weight among trade ministers because of its role as the lead UN institution charged by the international community with feeding the world's hungry and poor. The WFP's intervention made a deal on agriculture politically impossible at Hong Kong - food aid had become a toxic issue. To allay the perception that WTO rules would harm starving children, trade ministers concluded the ministerial with a statement they would work to maintain 'an adequate level of food aid' and develop a 'safe box' for bona fide food aid 'to ensure that there is no unintended impediment to dealing with emergency situations' (WTO 2005: 2).

The WFP's unprecedented intervention in the agricultural negotiations at Hong Kong had a lasting impact on subsequent bargaining. When WTO members returned to the negotiating table in 2006, they backpedaled on food aid rules and scrapped the text in the draft agricultural deal that had generated so much controversy at Hong Kong. This relieved WFP officials of their main concern that WTO rules would prevent the organization from drawing on surplus food commodities to feed vulnerable populations. ${ }^{12}$ The impact of the WFP is also evident in all the negotiating texts produced after Hong Kong but most notable in the Ministerial Decision on Export Competition made at the 2015 Nairobi Ministerial, in which states finally agreed to new WTO rules on food aid. These new rules include a 
commitment by trade ministers to maintain adequate levels of food aid, which had been a key WFP demand. The 2015 rules continue to permit surplus disposal food aid, which the WFP had preferred, with the exception where it may 'cause an adverse effect on local or regional production' (WTO 2015: 6). The rules omit any reference to the WTO deciding what constitutes a legitimate food aid emergency, leaving such a determination to humanitarian agencies, for which the WFP also called for.

WFP officials chose to intervene in the agricultural negotiations by invoking the organization's moral and delegated authority, rather than any claim to trade expertise, to challenge the legitimacy of trade rules by publicly depicting trade negotiators as recklessly endangering the lives of millions of food insecure people. The WFP's objective was to prevent new WTO rules coming into force that it perceived would hamper its ability to provide food assistance to vulnerable populations and thereby worsen world food insecurity. WFP officials also acted outside the formal channels by using the media as a platform to challenge the legitimacy of WTO trade rules. The WFP's interventions were rebuffed reputedly by the EU and Cairns Group - powerful players in the agricultural negotiations demonstrating that its officials attempted to influence the outcome of the negotiations even though the WFP's goals clashed with the commercial interests of states. Indeed, even in the face of opposition from powerful states, the WFP was successful in persuading WTO members to stop agreement on the proposed food aid rules at Hong Kong and to codify its demands into new agricultural trade rules agreed at the 2015 Nairobi Ministerial.

\section{The UN Special Rapporteur on the right to food at the WTO}

The final case demonstrates the efforts undertaken by the UN Special Rapporteur on the right to food to influence the agricultural negotiations. A key contribution by the Special Rapporteur was to advance the idea of an international legal waiver for food security as a 
solution to inter-state disagreement over public food stockholding. This proposal was taken up by states in the negotiations and was the basis for a pivotal WTO agreement.

The Special Rapporteur on the right to food is an independent expert appointed by the UN Human Rights Council and charged with monitoring and advocating for human rights issues at the nexus of food, agriculture and nutrition. Consecutive Special Rapporteurs, Jean Ziegler (2000-2008) and Olivier De Schutter (2008-2014), chose to devote significant parts of their mandates to influencing the WTO agriculture negotiations out of concerns about the potential negative consequences of agricultural trade rules for food insecure populations. The Special Rapporteurs, for example, have argued that human rights obligations trump international trade commitments and called on states to ensure that WTO negotiations do not result in outcomes that creates food insecurity for their own citizens or those of their trading partners (Fakhri 2015: 69; Joseph 2011).

Unlike the FAO or WFP, the Special Rapporteur on the right to food lacks observer status at the WTO and thus cannot formally participate in the agricultural negotiations. Under these conditions, the Special Rapporteurs used their UN platform as a moral authority to claim the right to be heard by trade negotiators. Take De Schutter's first act as Special Rapporteur, which was to undertake a fact-finding mission to the WTO to address what he perceived as the lack of coordination between human rights obligations and international trade commitments (De Schutter 2009). This mission focused on unequal bargaining relations among states and a key food security issue - import surges. In the report on his WTO mission, which was presented to the UN General Assembly and Human Rights Council, the Special Rapporteur recommended that governments should undertake human rights impact assessments prior to ratifying trade deals to ensure the human right to food was protected and that developing countries should limit their 'excessive reliance on international trade in the pursuit of food security' (De Schutter 2009: 20-23). The recommendations in this report drew 
the ire of Brazil, Canada and the US - all major agricultural exporters seeking liberalization at the WTO - and spurred these governments to instruct their delegates to the UN Human Rights Council to block a resolution approving the Special Rapporteur's recommendations; however, after a fierce debate, they failed in doing so after being outvoted by developing countries. ${ }^{13}$

De Schutter also engaged then-WTO Director-General Pascal Lamy in a series of high-profile public debates on WTO trade rules and their relationship to food security. While the debates signalled a greater willingness by WTO officials to discuss the human right to food, the debates were controversial among WTO members; agricultural exporting countries felt Lamy had overstepped his authority and given De Schutter 'too much credibility' by agreeing to the debates. ${ }^{14}$ Exporters labelled the Special Rapporteur's views as 'dangerous', saw him as a threat to the agricultural negotiations and sought to discredit him. ${ }^{15}$ In July 2009, pushed by several developing countries, the chairperson invited the Special Rapporteur to speak at the WTO Committee on Agriculture. The meeting was uncommonly heated, with afterwards one trade negotiator revealing that De Schutter had been set up for a 'clearly organized and orchestrated attack' by the agricultural exporting countries. ${ }^{16}$ Brazilian, Uruguayan and Australian officials aggressively criticised his views, questioned his neutrality and insisted he failed to understand the benefits trade brought to poor consumers. While the Special Rapporteur received statements of support from India and the African Group, he left the meeting shell-socked by the viciousness of the political attack against him. ${ }^{17}$

The Special Rapporteur decided to intervene again in the run up to the 2011 WTO Ministerial. This was the first WTO ministerial to discuss the effects of the 2008 Global Food Crisis - which drove over 1 billion people into hunger as wheat prices doubled and rice prices tripled. WTO members had agreed to discuss food security at the ministerial in response to new trade policy developments; for example, during the crisis more than 30 countries 
imposed food export bans to buffer domestic populations from higher prices but which further aggravated food shortages and created panic on world markets (Margulis 2014). Many developing countries also had started to implement public food stockholding programs (in which governments buy and store food commodities that are subsequently released to feed the hungry, alleviate food shortages and/or depress food prices). In 2013, India created the largest such program in the world; it made two-thirds of its 1.2 billion citizens eligible to purchase food at subsidized prices, in a country where undernutrition rates among children are $45 \%$ (Hertel 2015).

In the months preceding the ministerial, WTO members had become highly divided on the issue of how agricultural trade rules should contribute to addressing the consequences of the food crisis. Many developing countries claimed that WTO trade rules constrained their ability to implement public food stockholding programs. They cited rules that required them to count government purchases of foodstuffs as agricultural subsidies as being unfair. Unlike developed countries that had agreed to cap and reduce high levels of farm spending under the Agreement on Agriculture, most developing countries negotiated for very low or no spending on agricultural subsidies. At the time of the Uruguay Round most developing countries had been too highly indebted and engaged in structural adjustment to have imagined the need for space under WTO rules to provide agricultural subsidies in the future. This meant that developing countries implementing new food security programs ran the potential risk of violating WTO law. Developing countries had almost secured a fix to this problem by proposing technical changes to how agricultural subsidies were calculated for public food stockholding (Das 2016), however, this proposal was not agreed to because the negotiations collapsed in July 2008 due to North-South disagreement over other aspects of agriculture. As a result, developing countries were left facing uncertainty if their food security programs were legal under WTO law. 
Concerned about the potential 'chilling effect' (Eckersley 2004) of this legal uncertainty in discouraging pro-food security policies, the Special Rapporteur issued a report in the lead up to the 2011 WTO Ministerial that provided recommendations to governments on ways to ensure that trade rules supported the interests of food insecure populations. In addition to being circulated directly to WTO negotiators, the report was disseminated to over 10,000 subscribers to the Special Rapporteur's website and accompanied by commentary and opinion-editorials in the media. ${ }^{18}$ The report focused on public food stockholding on which the Special Rapporteur stressed that the complexity of WTO rules remained a significant impediment and that the proposed 'fix' to agricultural subsidy rules floated in July 2008 was insufficient. Instead, he proposed a legal waiver to end any uncertainty in existing WTO rules, suggesting that states 'simply adopt a statement that procurement rules do not apply to public stockholding of foodstuffs for food security purposes, or to waive the application of such rules' (De Schutter 2011:9). The Special Rapporteur supported developing countries' demands that stockholding be exempt from agricultural subsidy rules but went further than the technical solution sought by states by calling for WTO members to adopt the legal waiver 'for situations where trade commitments restrict a countries' ability to pursue national food security' (De Schutter 2011:16-17). The proposal for a waiver was novel in the context of agricultural negotiations and it had been proposed to provide developing countries with a blanket exemption to existing rules, similar to the 2001 waiver on intellectual property rights that enabled them to manufacture generic versions of essential medicines to protect public health. The Special Rapporteur's report made international headlines after the WTO DirectorGeneral criticized it in an open letter published on the WTO website shortly before the 2011 Ministerial (VanGrasstek 2013). In an unprecedented step, the WTO secretariat issued a lengthy technical paper disputing the Special Rapporteur's analysis and recommendations. ${ }^{19}$ The WTO's rebuttal, rather than discrediting De Schutter's recommendations to trade 
negotiators as intended, had the opposite effect by spurring developing countries and hundreds of international NGOs, labor unions and activist groups to rally around the Special Rapporteur and officially endorse the report's recommendations, including the idea of a food security waiver (Our World Is Not For Sale 2011).

The 2011 WTO ministerial concluded with only a vague statement for additional work on food security, however, there had been a major uptake of the Special Rapporteur's ideas. Developing country trade negotiators were seen carrying copies of the report at the Ministerial and had discussed it during bargaining strategy sessions. ${ }^{20}$ The report was heavily discussed by trade experts and became a key reference point for subsequent analysis on trade rules and food security. NGOs identified the legal waiver on food stockholding as a promising strategy for advancing developing countries' interests in the round (Dommen and Finnegan 2013).

The Special Rapporteur's recommendation for a legal waiver for public food stockholding resurfaced in advance of the 2013 Bali Ministerial in a negotiating proposal tabled by the G-33, a coalition of developing countries with food security concerns led by India and including China. WTO members had agreed to finalize a deal at Bali on a trade facilitation agreement and select issues pertaining to agriculture and special and differential treatment for least developed countries in the hope of restarting the stalled Doha negotiations (Narlikar and Tussie 2016). In the lead up to the Bali Ministerial, the G-33 made protecting public stockholding their negotiating priority (Bridges Weekly 2012). One reason for this was the very real risk of India's stockholding program breaching its agricultural subsidy limits. The G-33's bargaining proposal demanded a Peace Clause - a legal waiver - to ensure that developing countries could operate stockholding free from the spectre of a trade dispute. Agricultural exporters were unsettled by the proposal, fearing it would encourage food self- 
sufficiency in the global South, thereby undermining the WTO's built-in agenda of continued agricultural liberalization (Margulis 2014).

The Peace Clause on public food stockholding proved to be the most controversial issue at the Bali Ministerial. North-South disagreement on the Peace Clause nearly derailed the Ministerial (Wilkinson, Hannah and Scott 2014). The US was 'categorically against' exempting stockholding, which it viewed as effectively re-writing subsidy rules in a way that was more generous for developing countries prior to the completion of a full agricultural deal (Bridges Weekly 2013). The Indian Minister of Commerce and Industry, Anand Sharma, threatened to veto the deal on trade facilitation without an agreement on food stockholding, stating,

For India food security is non-negotiable. Governments of all developing nations have a legitimate obligation and moral commitment towards food and livelihood security of hundreds of millions of their hungry and poor. Public procurement at administered prices is often the only method of supporting farmers and building stocks for food security in developing countries. Need of public stockholding of food grains to ensure food security must be respected. (Sharma 2013)

An eleventh-hour US-India deal on the Peace Clause with additional negotiations on a permanent solution to be completed by 2017 salvaged the Ministerial. A key reason for the breakthrough at Bali was that the Ministerial Decision on the Peace Clause was written with sufficient ambiguity to allow both the US and India 'to emerge as winners' (Narlikar and Tussie 2016: 225). The US-India compromise was hailed as an historic success in leading to the first trade agreement completed since the creation of the WTO in 1994. Yet Bali was not decisive, as a few months later Indian Prime Minister Narendra Modi, who was unhappy with the pace of talks on a permanent solution for food stockholding, refused to ratify the trade facilitation agreement. Modi's gambit forced the US government into further bilateral negotiations; US firms, such as UPS, which were expected to be big winners from reducing the costs of trade under the Bali trade facilitation agreement, pressured the US government to make a deal. High-level talks between President Obama and Prime Minister Modi in 
September 2014 eventually resulted in a further bilateral deal that the Peace Clause would remain in effect until WTO members agreed to a permanent solution on food stockholding (thus abandoning the 2017 deadline).

While scholars have paid significant attention to the political contests over the Peace Clause at Bali, there has been far less consideration of the origins of this proposal. It is has been suggested that the Peace Clause was first suggested by China in 2013 (Singh and Gupta 2016: 321). While it is particularly difficult to trace the origins of ideas in trade negotiations, especially since many states and non-state actors have been involved in the policy debates on food stockholding, the evidence supports the claim that the Peace Clause advanced by the G33 was an adaptation of the Special Rapporteur's 2011 recommendation of a legal waiver. In over a decade of negotiations on public food stockholding at the WTO, including the tabling of 15 different bargaining proposals, states had not once proposed anything resembling a legal waiver prior to it being floated by the Special Rapporteur. All the pre-2011 proposals are consistent in seeking a technical solution for food stockholding, such as amendments to the formula in the Agreement on Agriculture for calculating subsidy spending (Das 2016). Similar technical solutions were also proposed by trade experts affiliated with UNCTAD, South Centre, and the International Centre for Trade and Sustainable Development. The Special Rapporteur's proposal, however, was different; lacking claims to trade expertise, his proposal instead sought to challenge the authority of international trade law by calling on states to opt-out of their WTO commitments if they clashed with their obligations to respect the human right to food of their citizens.

Two years after the idea was introduced by the Special Rapporteur to negotiators, the legal waiver was the centrepiece of the G-33's bargaining strategy. This is not coincidence as there are many links between the Special Rapporteur and the G-33. Multiple face-to-face exchanges took place between the Special Rapporteur and the G-33 negotiators prior to Bali, 
including an extensive discussion of his report - including the legal waiver - in March 2012 in Geneva. G-33 members were receptive to the Special Rapporteur's proposals; they regarded the Special Rapporteur as an ally since he had publicly supported the group's position in the negotiations and international recognition of De Schutter as a leading UN voice for global food security. Furthermore, De Schutter had discussed the legal waiver with the South Centre, a Southern intergovernmental think tank that works closely with the G-33 on their bargaining strategy at the WTO (Eagleton-Pierce 2013; Hannah, Ryan and Scott 2017). The South Centre had in fact peer-reviewed a draft of the Special Rapporteur's report and supported the recommendation of a legal waiver. ${ }^{21}$ Timing was also an important factor since by 2013 the G-33 needed an immediate solution to address the very real risk to India of a WTO trade dispute once the US had begun to signal it might take legal action. In this context, the legal waiver was a ready-made solution that ensured developing countries were not held over a barrel; a legal waiver provided the G-33 with the space to continue negotiating without the threat of a trade dispute. Even the Indian trade minister invoked the work of the Special Rapporteur on the right to food when arguing that food security was 'non-negotiable' (TWN 2013). The evidence is thus circumstantial but compelling that the G33 adopted the proposal for a legal waiver for food stockholding advanced by the Special Rapporteur on the right to food.

The Special Rapporteur on the right to food parlayed his moral authority as a UN voice for the vulnerable to influence the WTO agriculture trade negotiations. States did not request De Schutter's assistance - the decision to intervene in the negotiations was his alone. Powerful states and even the WTO secretariat made repeated attempts to prevent the Special Rapporteur from influencing the agricultural negotiations. The Special Rapporteur was motivated to intervene because of a concern that proposed trade rules undermined global efforts to promote food security. His interventions altered the negotiating dynamics by 
introducing the legal waiver as an option to end uncertainty over the legality of public food stockholding at the WTO. Despite not having formal access to the negotiations and lacking in trade expertise, WTO members were persuaded to take up the Special Rapporteur's proposal for a legal waiver. Following the resolution of a high stakes political fight between India and the US, two of the WTO's most powerful players, the Special Rapporteur's idea for a legal waiver for food stockholding became part of international trade rules.

\section{Conclusion}

This article has highlighted the role of UN actors as agents of change that undertake selfdirected initiatives and shape WTO rules on agriculture. Although lacking a formal seat at the bargaining table, I have demonstrated how each of the FAO, WFP and Special Rapporteur on the right to food influenced the discourse, agenda and outcomes of the agriculture negotiations. Self-initiated interventions in the GATT Uruguay Round by FAO officials changed the terms of the debate surrounding developing countries' food security concerns about higher food prices by reframing it as a balance of payments problem. More significantly, FAO officials worked unofficially behind the scenes to produce an agreement in favour of food insecure developing countries, showing that IO actors have also contributed to writing the rules of the WTO. The WFP invoked its moral authority at the 2005 Hong Kong ministerial to publicly condemn the trade deal on the table as being harmful to the world's hungry and poor; this intervention spurred WTO members to design different rules that incorporated the WFP's demands. The Special Rapporteur on the right to food utilized his moral claim to speak for the human rights of vulnerable groups and persuaded states to take up the recommendation of a legal waiver for public food stockholding, after which it was adopted as a new trade rule in 2013. Although each UN actor intervened on a different issue (i.e., balance of payments, international food aid, public food stockholding) and at different 
points in time, all three cases demonstrate that they acted in response to concerns that the WTO's expanded rule-making authority over agriculture would have negative consequences for world food security. Notably, these are all non-trade institutions - the FAO, WFP and Special Rapporteur on the right to food do not have mandates related to the governance of trade - that were influential in shaping the rules of the WTO.

The cases show that UN actors were the instigators of targeted interventions in the negotiations and not acting in response to requests by states for assistance. They utilized their delegated and moral authority rather than relying solely on trade expertise to persuade states to alter their behaviour. UN actors also undertook interventions outside official channels for IO participation, for example, by using the media and working behind the scenes to mobilize states to pursue a specific agenda. The three cases not only substantiate the argument that UN actors have successfully shaped rule-making at the WTO, they also demonstrate that IOs have played a much more agentic and impactful role in multilateral trade negotiations than has been previously acknowledged in the literature.

This study has focused on intervention in the agricultural negotiations by a number of UN institutions. There is reason to believe, however, that such intervention is not limited solely to UN institutions or to agriculture but likely a broader phenomenon. Many areas of WTO negotiations similarly have consequences for issues beyond trade, creating conditions where multiple IOs - and not just those limited to the 'UN family' - may have an interest and stake in the negotiation outcomes. Further research is therefore needed to more fully map the terrain of IO interventions at the WTO to determine the extent and frequency of this phenomenon across multiple negotiating areas. As a plausibility probe, this article has established the existence of an important phenomenon - that IOs have intervened to influence the course and outcomes of WTO trade negotiations. A next step toward theory development would be to establish the circumstances under which IOs choose to intervene or not, as well 
as understand when and why specific interventions succeed or fail. By unearthing the role of UN actors in influencing the negotiations on agricultural trade, this article opens up a new research agenda for trade scholarship that calls for taking seriously the agentic role of IOs in multilateral trade negotiations. Doing so is crucial to building a more complete understanding of who shapes the rules of the WTO.

\section{References}

Albin, Cecilia, and Ariel Young. 2012. 'Setting the table for success - or failure? Agenda management in the WTO.' International Negotiation 17(1): 37-64.

Babb, Sarah, and Nitsan Chorev. 2016. 'International organizations: loose and tight coupling in the development regime.' Studies in Comparative International Development 51(1): 81-102.

Barnett, Michael N., and Martha Finnemore. 2004. Rules for the World: International Organizations in Global Politics. Ithaca: Cornell University Press.

Barton, John H., Judith L. Goldstein, Timothy E. Josling, and Richard H. Steinberg. 2010. The Evolution of the Trade Regime: Politics, Law, and Economics of the GATT and the WTO. Princeton: Princeton University Press.

Bauer, Michael W, and Jörn Ege. 2017. 'A matter of will and action: the bureaucratic autonomy of international public administrations.' In Pp. 13-41 in International Bureaucracy: Springer. In Michael W. Bauer, Christoph Knil, and Stephen Eckhard (eds) International Bureaucracy. Public Sector Organizations. London: Palgrave Macmillan, pp. 13-41.

Belgasmi, Daly 2006. 'International obligations for providing food aid.' Refugee Survey Quarterly 25(4): 179-90.

Biermann, Frank, and Bernd Siebenhüner (eds). 2009. Managers of Global Change: The Influence of International Environmental Bureaucracies. Cambridge: Massachusetts Institute of Technology Press.

Bridges Weekly. 2004. 'Ag Committee: Members Question US Aid Program'" Geneva: ICTSD.

—. 2012. 'Developing Countries Table Food Security Proposal at WTO.' Geneva: ICTSD.

—. 2013. '"Peace Clause" Controversy Pushes Bali Deal into Eleventh Hour'" Geneva: ICTSD.

Broome, André, Alexandra Homolar, and Matthias Kranke. Forthcoming. 'Bad science: international organizations and the indirect power of global benchmarking.' European Journal of International Relations.

Broome, André, and Leonard Seabrooke. 2015. 'Shaping policy curves: cognaitive authroity in transnatonal capacity building.' Public Administration 93(4): 956-72.

Bukovansky, Mlada. 2010. 'Institutionalized hypocrisy and the politics of agricultural trade.' In Rawi Abdelal, Mark Blyth, and Craig Parsons (eds), Constructing the International Economy. Ithaca: Cornell University Press, pp. 68-90. 
Chorev, Nitsan. 2012. The World Health Organization Between North and South. Ithaca: Cornell University.

Chorev, Nitsan, and Sarah Babb. 2009. 'The crisis of neoliberalism and the future of international institutions: a comparison of the IMF and the WTO. Theory and Society 38(5): 459-84.

Chwieroth, Jeffrey M. 2009. Capital Ideas: The IMF and the Rise of Financial Liberalization. Princeton: Princeton University Press.

Clapp, Jennifer. 2012. Hunger in the Balance: The New Politics of International Food Aid. Ithaca: Cornell University Press.

—. 2015. 'Food security and contested agricultural trade norms.' Journal of international Law and International Relations 11(2): 104-15.

Coleman, William D, Wyn Grant and Timothy E. Josling. 2004. Agriculture in the New Global Economy. Cheltenham: Edward Elgar.

Das, Sannoy. 2016. 'Food security amendments to the WTO green box: a critical reexamination.' Journal of World Trade 50(6): 1111-1132.

Davis, Christina L. 2003. Food Fights Over Free Trade: How International Institutions Promote Agricultural Trade Liberalization. Princeton: Princeton University Press.

Daugbjerg, Carsten, Arild Aurvåg Farsund and Oluf Langhelle. 2017. 'The resilience of paradigm mixes: food security in a post-exceptionalist trade regime.' Journal of European Public Policy 24(11): 1698-1715.

De Schutter, Olivier. 2009. Mission to the World Trade Organization. Geneva: OHCHR.

- 2011. The World Trade Organization and the Post-Global Food Crisis Agenda: Putting Food Security First in the International Trade System. Geneva: OHCHR.

Deardorff, Alan V. 2004. 'Who makes the rules of globalization?' CESifo Working Paper Series 1301, Munich: CESifo Group.

Deere, Carolyn. 2005. Changing the Power Balance at the WTO: Is the Capacity-Building Agenda Helping? Geneva: UNDP.

Dommen, Caroline, and Lynn Finnegan. 2013. New Framework for Trade and Investment in Agriculture: Draft Mapping of Alternative Proposals. Geneva: Quaker UN Office.

Eagleton-Pierce, Matthew D. 2012. 'The competing kings of cotton: (re)framing the WTO African cotton initiative.' New Political Economy 17(3): 313-37.

—. 2013. Symbolic Power in the World Trade Organization. Oxford: Oxford University Press.

Eckersley, Robyn 2004. 'The big chill: the WTO and multilateral environmental agreements.' Global Environmental Politics 4(2): 24-50.

Eckstein, Harry. 2009. 'Case study and theory in political science.' In Roger Gomm, Martyn Hammersley and Peter Foster (eds) Case Study Method. London: Sage, pp. 118-64.

European Union (EU). 2005. 'Food Aid: EU urges US reform.' 14 December. Brussels: EU.

Fakhri, Michael. 2015. 'Food as a matter of global governance.' Journal of international Law and International Relations 11(2): 68-83.

Food and Agricultue Organization (FAO). 1986. 'Food and Agriculture Organization:

Statement by Mr. J.C. Vignaud. Representative, Office in Geneva.' Geneva: GATT.

-. 1987a. FAO Council Ninety-first Session: Verbatim Report. Rome: FAO.

—. 1987b. Impact on World Food Security of Agriculural Policies in Industrialized

Countries. Rome: FAO.

—. 1990. The State of Food and Agriculture 1989. Rome: FAO.

-. 1991a. FAO Council Ninety-ninth Session: Verbatim Report. Rome: FAO.

—. 1991b. The State of Agriculture and Food 1990. Rome: FAO. 
Farsund, Arild Aurvåg, Carsten Daugbjerg, and Oluf Langhelle. 2015. 'Food security and trade: reconciling discourses in the Food and Agriculture Organization and the World Trade Organization.' Food Security 7(2): 383-91.

General Agreement on Tariffs and Trade (GATT). 1988a. Summary of Main Points Raised at the Eleventh Meeting of the Negotiating Group on Agriculture. Geneva: GATT.

—. 1988b. Trade Negotiations Committee Meeting at Ministerial Level. Geneva: GATT.

- 1989. Ways to Take Account of the Negative Effects of the Agriculture Reform Process on Net-Food Importing Developing Countries. Geneva: GATT.

- 1991. Draft Final Act Embodying the Results of the Uruguay Round of Multilateral Trade Negotiations. Geneva: GATT.

Gehring, Thomas, and Benjamin Faude. 2014. 'A theory of emerging order within institutional complexes: how competition among regulatory international institutions leads to institutional adaptation and division of labor.' The Review of International Organizations 9(4): 471-498.

George, Alexander L., and Andrew Bennett. 2005. Case Studies and Theory Development in the Social Sciences. Cambridge: MIT Press.

Grabel, Ilene. 2007. 'Policy coherence or conformance? The new World Bank-International Monetary Fund-World Trade Organization rhetoric on trade and investment in developing countries.' Review of Radical Political Economics 39(3): 335-41.

Hannah, Erin N. 2014. 'The quest for accountable governance: Embedded NGOs and demand driven advocacy in the international trade regime.' Journal of World Trade 48(3): 457-79.

Hannah, Erin N., Holly Ryan, and James Scott. 2017. 'Power, knowledge and resistance: between co-optation and revolution in global trade.' Review of International Political Economy 24(5): 741-75.

Hannah, Erin N., James Scott, and Silke Trommer. 2015. Expert Knowledge in Global Trade. London: Routledge.

Hawkins, Darren G., David A. Lake, Daniel Nielson and Michael J. Tierney. 2006. Delegation and Agency in International Organizations. Cambridge: Cambridge University Press.

Hertel, Shareen. 2015. 'Hungry for justice: social mobilization on the right to food in India.' Development and Change 46(1): 72-94.

Hopewell, Kristen. 2013. 'New protagonists in global economic governance: Brazilian agribusiness at the WTO.' New Political Economy 18(4): 603-23.

-. 2015. 'Multilateral trade governance as social field: global civil society and the WTO.' Review of International Political Economy 22(6): 1128-58.

—. 2016. Breaking the WTO: How Emerging Powers Disrupted the Neoliberal Project. Stanford: Stanford University Press.

Johnson, Tana. 2013. 'Looking beyond states: Openings for international bureaucrats to enter the institutional design process.' The Review of International Organizations 8(4): 499519.

Joseph, Sarah. 2011. Blame it on the WTO?: A Human Rights Critique. Oxford: Oxford University Press.

Khor, Martin. 2005. 'More finger pointing, less negotiation, as Ministerial gets under way.' 15 December. Geneva: Third World Network.

Lang, Andrew, and Joanne Scott. 2009. 'The hidden world of WTO governance.' European Journal of International Law 20(3): 575-614.

Levy, Jack S. 2008. 'Case studies: types, designs, and logics of inference.' Conflict Management and Peace Science 25(1): 1-18. 
Mably, Paul. 2009. 'Centralized production: the Group of 33.' In Diana Tussie (ed), The Politics of Trade, Leiden: Martinus Nijhoff Publishers, pp. 239-70.

Margulis, Matias E. 2013. "The regime complex for food security: implications for the global hunger challenge." Global Governance 19(1): 53-67.

—. 2014. "Trading out of the global food crisis? The World Trade Organization and the geopolitics of food security." Geopolitics 19(2): 322-50.

—. 2017. 'The forgotten history of food security in the multilateral trading system.' World Trade Review 16(1): 25-57.

Morris, James T. 2005. 'We Are Solely Concerned for Needs of Poor and Hungry.' 15 December. The Financial Times.

Murphy, Hannah. 2010. The Making of International Trade Policy: NGOs, Agenda-setting and the WTO. Cheltenham: Edward Elgar.

Muzaka, Valbona. 2011. The Politics of Intellectual Property Rights and Access to Medicines. London: Palgrave Macmillan.

Narlikar, Amrita. 2003. International Trade and Developing Countries: Bargaining Coalitions in the GATT and WTO. Abingdon and New York: Routledge.

Narlikar, Amrita and Diana Tussie. 2016. 'Breakthrough at Bali? Explanations, aftermath, implications.' International Negotiation 21(2): 209-32.

Nielson, Daniel L., and Michael J. Tierney. 2003. 'Delegation to international organizations: agency theory and World Bank environmental reform.' International Organization 57(2): 241-76.

Oestreich, Joel E. 2012. International Organizations as Self-directed Actors: A Framework for Analysis. Abingdon and New York: Routledge.

Our World Is Not For Sale. 2011. 'Statement of Our World Is Not for Sale on the de SchutterWTO Debate.' 17 December.

Paarlberg, Robert. 1997. 'Agricultural policy reform and the Uruguay Round: synergistic linkage in a two-level game?' International Organization 51(03): 413-44.

Powell, John. 2005. Statement by the Deputy Executive Director of the WFP. Rome: WFP.

Prowse, Susan. 2002.' The role of international and national agencies in trade-related capacity building.' The World Economy 25(9): 1235-61.

Quark, Amy A. 2013. Global Rivalries: Standards Wars and the Transnational Cotton Trade. Chicago: University of Chicago Press.

Reinalda, Bob, and Bertjan Verbeek. 1998. Autonomous Policy Making by International Organisations. Abingdon and New York: Routledge.

Scott, James. 2008. 'The use and misuse of trade negotiation simulations.' Journal of World Trade 42(1): 87-103.

- 2015. 'The role of Southern intellectuals in contemporary trade governance.' New Political Economy 20(5): 633-52.

Sell, Susan K. 2009. 'Coorporations, seeds and intellectual property rights governance.' In Jennifer Clapp and Doris A Fuchs (eds), Corporate Power in Global Agrifood Governance. Cambridge: MIT Press, pp. 187-224.

Shaffer, Gregory. 2005. "Can WTO technical assistance and capacity-building serve developing countries?" Wisconson International Law Journal 23(4): 643-86.

Sharma, Anand. 2013. Address by Shri Anand Sharma Union Minister of Commerce and Industry at the Plenary Session of the 9th Ministerial Conference of the WTO. 4 December 2013. Geneva: WTO.

Shaw, D. John. 2007. World Food Security: A History Since 1945. London: Palgrave Macmillan. 
Singh, J.P., and Surupa Gupta. 2016. 'Agriculture and its discontents: coalitional politics at the WTO with special reference to India's food security interests.' International Negotiation 21(2): 295-326.

Smeets, Maarten. 2013. 'Trade capacity building in the WTO: main achievements since Doha and key challenges.' Journal of World Trade 47(5):1047-90.

Steinberg, Richard H. 2002. 'In the shadow of law or power? Consensus-based bargaining and outcomes in the GATT/WTO.' International Organization 56(02): 339-74.

Taylor, Ian. 2003. 'The United Nations Conference on Trade and Development.' New Political Economy 8(3): 409-18.

Third World Network (TWN). 2013. 'Minister Sharma explains India's position on food security.' Geneva: TWN.

UN News Centre. 2005. 'UN agency heads call on world trade negotiators to protect in-kind food aid' 8 December 2005.

United Nations Conference on Trade and Development (UNCTAD). 2004. Report of the United Nations Conference on Trade and Development on its tenth session. Geneva: UNCTAD.

United States Trade Representative (USTR). 2005. 'Briefing by USAID Administrator Natsios and Deputy U.S. Trade Representative Bhatia'. 14 December 2005. Washington: USTR.

VanGrasstek, Craig. 2013. The History and Future of the World Trade Organization. Geneva: WTO.

Walch, Karen S. 2003. 'Feminist ideas on cooperation and self-interest for international relations." In Mary Ann Tétreault and Robin L. Teske (eds), Partial Truths and the Politics of Community. Columbia: University of South Carolina Press, pp. 161-79.

Wilkinson, Rorden. 2009. 'Language, power and multilateral trade negotiations.' Review of International Political Economy 16(4): 597-619.

—. 2014. What's Wrong with the WTO and How to Fix It. Cambridge: Polity.

Wilkinson, Rorden, Erin Hannah, and James Scott. 2014. 'The WTO in Bali: what MC9 means for the Doha development agenda and why it matters.' Third World Quarterly 35(6): 1032-50.

Williams, Frances 2005. 'Move by WTO 'is threat to food aid'. The Financial Times. 9 May.

Wolfe, Robert. 1998. Farm Wars: The Political Economy of Agriculture and the International Trade Regime. Basingstoke: Macmillan.

World Trade Organization (WTO). 2005. Ministerial Declaration: Adopted on 18 December 2005. Geneva: WTO.

—. 2015. Export Competition: Ministerial Decision of 19 December 2015. Geneva: WTO.

\section{Endnotes}

\footnotetext{
${ }^{1}$ The provision of demand-driven assistance is not exclusive to international organizations. The WTO secretariat, non-governmental organizations, and national government departments, such as the United States Agency for International Development (USAID), also provide technical trade assistance.

2 The WTO is not part of the UN system; however, it has formalized relationship with over 60 international organizations (see VanGrasstek 2013: 153-155).

${ }^{3}$ UNCTAD, which is the UN institution with the most interaction with the GATT/WTO, is not selected as a case. Instead, I selected other institutions without trade mandates to show that other international organizations intervening in multilateral trade negotiations is a much broader phenomenon.

${ }^{4}$ Trade ministers declared the Doha Round to have reached an impasse in December 2011.
} 
5 The members of the Cairns Group during the Uruguay Round included Argentina, Australia, Brazil, Canada, Chile, Colombia, Fiji, Hungary, Indonesia, Malaysia, New Zealand, the Philippines, Thailand and Uruguay. It now includes 19 countries.

${ }^{6}$ Confidential interview with former senior FAO official (February 2009).

${ }^{7}$ Confidential interviews with current and former senior FAO officials (February and March 2009).

${ }^{8}$ Confidential interviews with current and former senior FAO officials (February and March 2009).

${ }^{9}$ Confidential interview with senior WFP official (May 2008).

${ }^{10}$ Confidential interview with senior WFP official (May 2008); communications with former Cairns Group countries trade negotiators (March and April 2009).

${ }^{11}$ Multiple confidential interviews with former Cairns Group trade negotiators between October 2008 and April 2009.

${ }^{12}$ Interview with Charles Vincent, Director of WFP Liaison Office in Geneva (March 2009).

${ }^{13}$ Direct observation of UN Human Rights Council $10^{\text {th }}$ Session (March 2009), including breakout session on drafting of the resolution on De Schutter's report on the mission to the WTO.

${ }^{14}$ This section draws on multiple confidential interviews with developed and developing country trade negotiators undertaken between October 2008 and April 2009.

${ }^{15}$ Confidential interview with developing country negotiator (April 2009).

${ }^{16}$ Confidential interview with developed and developing country negotiators (July and August 2009).

${ }^{17}$ Interview with Olivier De Schutter (July 2009); personal communication with Olivier De Schutter (November 2009).

${ }^{18}$ Personal communication with communications officer for the UN Special Rapporteur on the right to food (January 2012).

${ }^{19}$ Lamy's letter and the WTO Secretariat paper are available at:

https://www.wto.org/english/news_e/news11_e/agcom_14dec11_e.htm\#letter

${ }^{20}$ Personal communications with Oliver De Schutter (January 2012).

${ }^{21}$ Personal communications with advisor to the UN Special Rapporteur on the right to food (December 2011)

and Aileen Kwa, Coordinator of Trade for Development Programme for the South Centre (November 2011) 